\title{
PERANCANGAN DAN IMPLEMENTASI GAME SIMULASI UNTUK MENGETAHUI NEUROTISME BERDASARKAN INTERNATIONAL PERSONALITY ITEM POOL
}

\author{
Thomas Galih Satria ${ }^{1}$, Francisco Maruli Panggabean ${ }^{2}$, Hantze Sudarma ${ }^{3}$ \\ 1,2,3 Program Studi Teknik Informatika, Universitas Bina Nusantara, Jakarta Indonesia \\ E-mail: ${ }^{1}$ tsatria@binus.edu, ${ }^{2}$ fpanggabean@ binus.edu, ${ }^{3}$ hsudarma@ binus.edu
}

\begin{abstract}
The game or game is an interactive activity that can quickly provide feedback between players and the system. Players can learn through discovery, practice, and feedback rather than absorb information so that it is easier to transfer the knowledge they gain from playing experience to the real world of work. The International Personality Item Pool - Neuroticism, Extraversion \& Openness (IPIP-NEO) is a personality test based on the Big Five Personality theory in which the test takes the form of a questionnaire. The purpose of this research is to design an alternative media in using IPIP-NEO especially the neuroticism part in a simulation game. The problem raised was that IPIP-NEO's personality test was a questionnaire that did not provide a situation description of the questions asked to respondents. Based on existing problems, data collection in the form of literature studies, questionnaires, and interviews with experts, can be made the need for making games. The game results are then evaluated using a questionnaire aimed at samples from Non Probability Purposive Sampling. Based on the evaluation results from the questionnaire, NeuroTest gets $76 \%$ of users who feel that the results of the game provide the right depiction for themselves.
\end{abstract}

Keywords: Game, Questionnaire, Neurotism, IPIP-NEO

\begin{abstract}
ABSTRAK
Permainan atau game merupakan aktivitas interaktif yang dapat secara cepat memberikan umpan balik antara pemain dan sistem. Pemain dapat belajar melalui penemuan, latihan, dan umpan balik daripada menyerap informasi sehingga lebih mudah melakukan transfer pengetahuan yang mereka dapatkan dari pengalaman bermain ke dunia kerja sesungguhnya. International Personality Item Pool - Neuroticism, Extraversion \& Openness (IPIP-NEO) merupakan sebuah tes kepribadian yang didasari atas teori Big Five Personality di mana tes tersebut berbentuk kuesioner. Tujuan dari penelitian ini adalah untuk merancang sebuah media alternatif dalam menggunakan IPIP-NEO khususnya bagian neurotisme ke dalam sebuah game simulasi. Masalah yang diangkat adalah tes kepribadian IPIP-NEO merupakan sebuah kuesioner yang tidak memberikan gambaran situasi akan pertanyaan yang ditanyakan kepada responden. Berdasarkan masalah yang ada, pengumpulan data berupa studi pustaka, kuesioner, dan wawancara kepada pakarnya, dapat dibuat kebutuhan pembuatan game. Hasil game kemudian dievaluasi menggunakan kuesioner yang ditujukan kepada sampel dari Non Probability Purposive Sampling. Berdasarkan hasil evaluasi dari kuesioner, NeuroTest mendapatkan $76 \%$ pengguna yang merasa bahwa hasil dari game memberikan penggambaran yang tepat untuk dirinya.
\end{abstract}

Kata Kunci: Game, Kuesioner, Neurotisme, IPIP-NEO

\section{PENDAHULUAN}

Banyak tes kepribadian yang bersifat kuesioner dan hanya terdiri dari berbagai macam pernyataan yang harus dibaca oleh seorang individu yang menyebabkan kemalasan, hal ini disebabkan karena kuesioner yang relatif berbentuk pernyataan dan juga hitam putih. Hal ini menimbulkan suatu sifat malas yang merupakan sifat dasar manusia ketika melihat hal yang relatif tanpa warna dan juga berupa tulisan. Permainan atau game merupakan aktivitas interaktif yang dapat secara cepat memberikan umpan balik antara pemain dan sistem. Sistem komputer seperti simulasi dan animasi dapat memberikan pengalaman belajar yang kongkrit kepada para user atau pengguna. Pemain dapat belajar melalui penemuan, latihan, dan umpan balik daripada menyerap informasi sehingga lebih mudah melakukan transfer pengetahuan yang mereka 
dapatkan dari pengalaman bermain ke dunia kerja sesungguhnya.

Neuroticism Trait ini menilai kestabilan dan ketidakstabilan emosi. Mengidentifikasi kecenderungan individu apakah mudah mengalami stres, mempunyai ide-ide yang tidak realistis, mempunyai coping response yang maladaptif (Mastuti, 2005).

Dimensi ini menampung kemampuan seseorang untuk menahan stres. Orang dengan kemantapan emosional positif C. D. Ino Yuwono, M. G. Bagus Ani Putra cenderung berciri tenang, bergairah dan aman. Sementara mereka yang skornya negatif tinggi cenderung tertekan, gelisah dan tidak aman (Mastuti, 2005).

Komponen dari big five faktor tersebut menurut NEO PI-R yang dikembangkan Costa \& McCrae (Pervin \& John, 2001) adalah:

\section{Neuroticism Kecemasan (Anxiety)}

Kemarahan (Anger) Depresi (Depression)

Kesadaran diri (Self-consciousness) Kurangnya kontrol diri (Immoderation) Kerapuhan (Vulnerability).

IPIP-NEO merupakan salah satu jenis tes kepribadian dengan bentuk kuesioner yang memiliki penilaian berdasarkan Big Five Personality yaitu Openness, Conscientiousness, Extraversion, Agreeableness dan Neuroticism. Tes kepribadian IPIP-NEO berbasis pengetahuan ilmiah dan umumnya diterima di seluruh dunia sebagai salah satu kuesioner kepribadian yang akurat. IPIP-NEO bisa sangat menguntungkan bagi perusahaan yang merekrut pegawai dalam jumlah sangat banyak, karena mereka dapat membandingkan skor antara kandidat yang mungkin dan sesuai dengan pekerjaan tersebut.

Penelitain Terdahulu yang dilakukan oleh Endah Mastuti berjudul Analisis Faktor Alat Ukur Kepribadian Big Five (Adaptasi dari IPIP) pada Mahasiswa Suku Jawa. Perkembangan kepribadian big five sangat pesat dalam berbagai riset kepribadian. Berbagai penelitian telah menunjukkan bahwa banyak hal yang mampu diprediksi dengan trait-trait dalam kepribadian big five. Sejalan dengan hal tersebut, berbagai alat ukur telah dikembangkan untuk mengukur kepribadian big five. Penelitian ini bertujuan ingin mengadaptasi salah satu alat ukur kepribadian big five yang diambil dari International Personality Item Pool (IPIP) dan menguji validitas konstraknya di suku Jawa sehingga penggunaan taksonomi tentang alat tes ini bisa dikembangkan dan diaplikasikan di Indonesia, khususnya di suku Jawa. Selain itu, ingin membuktikan validitas aitem, reliabilitas alat ukur kepribadian big five yang diadaptasi dari International Personality Item Pools (IPIP) tersebut. Subyek penelitian ini adalah 110 mahasiswa Fakultas Psikologi Universitas
Airlangga. Metode yang digunakan adalah analisis faktor eksploratori untuk menguji validitas konstraknya. Hasil penelitian menunjukkan bahwa validitas konstrak alat ukur kepribadian big five yang diambil dari International Personality Item Pools (IPIP) dengan sampel mahasiswa Jawa, tidak terbukti. Hal ini karena data yang didapatkan tidak sesuai dengan teori kepribadian big five yang diteorikan. Pada penelitian ini dengan analisis faktor menunjukkan bahwa trait kepribadian terdiri dari 6 faktor yaitu Neuroticism, Extraversion, Opennes to Experience, Agreeableness, Conscientiousness dan Morality (Mastuti, 2005).

Penelitain Terdahulu yang dilakukan oleh Zummy Anselmus Dami, Santi Curniati berjudul Pola Asuh Autoritatif dan Jenis Kelamin sebagai Prediktor Big Five Personality Factors: Implikasinya Bagi Pelayanan Bimbingan dan Konseling Hasil analisis data deskriptif masingmasing variabel menunjukkan bahwa sebagian besar subjek memiliki tingkat kepribadian emotional stability/neuroticism yang berada pada kategori rendah, yakni 50\% (std deviation 4,244); agreeableness yang berada pada kategori tinggi, yakni 38,3\% (std. deviation 6,480); conscientiousness yang berada pada kategori tinggi, yakni $46,7 \%$ (std deviation 5,081); extraversion yang berada pada kategori rendah, yakni 58\% (std deviation 5,295); dan openness to experience yang berada pada kategori tinggi, yakni $45 \%$ (std deviation 5,598). Sedangkan untuk variabel pola asuh autoritatif orangtua, sebagian besar subjek penelitian berada pada kategori yang sangat tinggi 39\% (std deviation 16,710). Uji prasyarat dilakukan sebelum uji hipotesis. Uji prasyarat yang pertama dilakukan adalah uji normalitas. Hasil uji normalitas menunjukkan bahwa nilai signifikansi dari uji KolmogorovSmirnov sebesar 0,387>0,05 (emotional stability); 0,709>0,05 (agreeableness); $0,636>0,05$ (conscientiousness); 0,791>0,05 (extraversion); $0,693>0,05$ (openness to experience), dan $0,592>0,05$ (pola asuh autoritatif atau demokratis), sehingga dapat diketahui bahwa data berdistribusi normal seperti yang disajikan pada tabel 3. Dengan demikian, analisis MANCOVA dapat dilanjutkan. Uji prasyarat yang kedua, yaitu Box's Test. Output nilai Box's Test sebesar 5,434 dengan taraf signifikansi 0,673. Berdasarkan kriteria pengujian dengan signifikansi 0,05 , maka nilai Box's Test yang diperoleh tidak signifikan karena signifikansi yang diperoleh $0,673>0,05$. Dengan demikian hipotesis nol diterima, berarti matriks kovarian dari variabel dependen sama, sehingga analisis MANCOVA dapat dilanjutkan seperti yang disajikan pada tabel 4. Uji prasyarat ketiga, yaitu uji homogenitas varian. Berdasarkan Levene's Test didapat nilai signifikansi emotional stability 0,392 $>0,05 ;$ agreeableness $0,937>0,05$; conscientiousness $0,223>0,05$; extraversion 0,192 $>0,05$; dan openness to experience $0,254>0,05$, 
hasil Levene's Test secara lebih jelas disajikan pada tabel 5. Dengan melihat hasil Levene's Test, maka dilanjutkan dengan uji MANCOVA. Hasil analisis MANCOVA menunjukkan bahwa jenis kelamin terhadap emotional stability diperoleh nilai signifikansi 0,136 ; agreeableness diperoleh nilai signifikansi 0,312 ; conscientiousness diperoleh nilai signifikansi 0,713 ; extraversion diperoleh nilai signifikansi 0,896 ; dan openness to experience diperoleh nilai signifikansi 0,209. Semuanya lebih besar dari 0,05, maka dapat diketahui bahwa tidak ada pengaruh jenis kelamin terhadap big five personality. Untuk pola asuh autoritatif orangtua terhadap emotional stability diperoleh nilai signifikansi 0,854 ; agreeableness diperoleh nilai signifikansi 0,424; conscientiousness diperoleh nilai signifikansi 0,629; extraversion diperoleh nilai signifikansi 0,000; dan openness to experience diperoleh nilai signifikansi 0,616. Berdasarkan hasil ini, ditemukan bahwa ada pengaruh signifikan pola asuh demokratis orangtua terhadap extraversion dengan nilai signifikansi $0,012<0,05$. Pola asuh demokratis orang tua tidak berpengaruh pada emotional stability; agreeableness; conscientiousness; dan openness to experience karena nilai signifikansi lebih besar dari 0,05 Untuk interaksi antara jenis kelamin dan pola asuh demokratis orangtua terhadap emotional stab ility $(0,114>0,05)$; agreeableness $\quad(0,332>0,05)$; conscientiousness (Dami \& Curniati, 2018).

120-item Item Kepribadian Internasional Pool-NEO-120 (IPIP-NEO-120; Johnson, 2014) adalah revisi singkat dari 300-item Item Kepribadian Internasional Pool-NEO (IPIP-NEO300; Goldberg, 1999), yang mengukur konstruksinya serupa dengan yang ada dalam NEO Personality Inventory (NEO PI-R; Costa \& McCrae, 1992). Revisi ini, dibuat dari sampel Internet, mewakili kedua domain 5 (Neuroticism, Extraversion, Conscientiousness, Agreeableness, dan Openness to Experience) dan 30 aspek dari Five Factor Model dengan 4 item per skala facet (120 item). Konstruksi skala didasarkan pada skala IPIP-NEO 10-item yang ada untuk masing-masing 30 aspek; 4 item dipilih dari setiap skala. Tidak seperti IPIP-NEO-300, IPIP-NEO-120 tidak memiliki proporsi seimbang dari item-item dengan kunci positif dan negatif untuk setiap aspek. Secara keseluruhan, ada 65 item dengan kunci positif dan 55 item dengan kunci negatif. Properti psikometrik dinilai dengan 4 sampel: sampel komunitas Eugene-Springfield (Goldberg, 2008), yang menyelesaikan IPIP-NEO-300; 2 sampel internet dan sampel lokal. Cabilitas alfa Cronbach untuk skala sisi 4-item sedikit lebih rendah daripada alfa untuk skala sisi 10 item (rata-rata alfa 0,80 vs 0,68 dalam sampel komunitas dan 0,82 vs 0,75 dalam sampel Internet), tetapi mereka mempertahankan keandalan yang cukup. Validitas konstruk juga didukung. Analisis komponen utama dengan rotasi varimax menunjukkan bahwa, meskipun 5 faktor kepribadian mayoritas biasanya jelas diwakili oleh pemuatan di ketiga analisis, tidak semua aspek menunjukkan pemuatan tertinggi pada komponen yang diharapkan (Johnson, 2014).

Oleh karena itulah, penulis merumuskan adanya solusi untuk prediksi dan tes alternatif untuk IPIP-NEO. Hal ini juga dapat digunakan dalam tes kepribadian yang tentu saja akan sangat membantu individu dalam mengukur kepribadian dirinya sendiri jika dirancang dalam bentuk game.

Penulis memutuskan untuk membuat serious game yang berupa sebuah simulasi dari tes kepribadian IPIP-NEO. Tes ini merupakan tes kepribadian berbasiskan Big Five Personality yang terdiri dari kuesioner yang akan dibuat simulasinya dengan beberapa situasi berdasarkan item-item yang ada pada tes ini. Dalam pembuatan game ini, tim penulis terfokuskan pada pembuatan simulasi di bidang neurotisme yang ada pada Big Five Personality.

IPIP-NEO akan diadopsi kedalam sebuah game untuk menjadi alat tes alternatif dan sebagai alat prediksi. Pembuatan gameplay diawali dengan melakukan wawancara kepada narasumber yang berpengalaman. Selanjutnya membuat plot cerita yang menggambarkan 6 (enam) situasi dari sifat.

\section{METODE PENELITIAN}

Metode penelitian yang dilakukan dalam penelitian ini terdiri dari pengumpulan data berupa wawancara dan kuesioner.

Dalam pengumpulan data, metode yang dibahas adalah (Sani, 2018):

\section{Wawancara}

Wawancara dilakukan dengan narasumber di bidangnya yang bertujuan untuk mendapatkan informasi yang dibutuhkan dalam beberapa bidang yang terkait dengan penelitian ini.

Dalam proses pengumpulan data, penulis bertemu dengan DR. Johannes A. A. Rumeser, M.PSI, seorang dekan psikologi di salah satu kampus. Penulis mewawancarai beliau dengan tujuan untuk mendapatkan informasi-informasi mengenai tes kepribadian yang ada dan penulis juga memberitahu beliau bahwa adanya wawancara ini peneliti ingin membuat sebuah game yang tujuannya adalah sebagai salah satu media alat ukur yang lebih interaktif. Penulis berkata demikian karena dasar dari pembuatan tes ini adalah IPIPNEO Test yang merupakan sebuah tes dengan melakukan pemilihan jawaban. Beliau pun memberikan masukan-masukan seperti melihat terlebih dahulu parameter apa yang sebenarnya ingin dibuat dalam tes kepribadian ini, terutama di bagian Neurotisme.

\section{Kuesioner}


Kuesioner dilakukan dengan memberikan beberapa pertanyaan kepada target player game yang akan dibuat dimana pertanyaan yang diberikan merupakan pertanyaan untuk menentukan apakah asumsi yang telah dibuat oleh peneliti benar atau tidak. Juga untuk mendapatkan informasi tentang kebutuhan dari target player yang akan dituju. Pada penyebaran kuesioner pertama peneliti yang bertujuan untuk menyesuaikan kebutuhan dengan data yang ada di lapangan, peneliti menyebarkan kuesioner ini kepada mahasiswa-mahasiswi yang ada di universitas. Target yang ingin didapatkan oleh peneliti sejumlah 100 responden. Namun, responden yang masuk sebelum kuesioner ditutup mencapai 160 responden (Pujihastuti, 2010).

\section{HASIL DAN PEMBAHASAN}

Pada penyebaran kuesioner pertama peneliti yang bertujuan untuk menyesuaikan kebutuhan dengan data yang ada di lapangan, peneliti menyebarkan kuesioner ini kepada mahasiswa-mahasiswi yang ada di universitas. Target yang ingin didapatkan oleh peneliti sejumlah 100 responden. Namun, responden yang masuk sebelum kuesioner ditutup mencapai 160 responden. Berikut hasil dari Kuesioner yang telah disebar:

Untuk poin Depression, poin-poin yang akan diukur adalah sebagai berikut :
a. Often feel blue
b. Dislike myself
c. Often down in the dumps
d. Feel comfortable with myself

Self-Consciousness (rata-rata skor : 13.45)

Untuk poin Self-Consciousness, poin-poin yang akan diukur adalah sebagai berikut:
a. Find it difficult to approach others
b. Afraid to draw attention to myself
c. Only feel comfortable with friends
d. Not bothered by difficult social situations Immoderation (rata-rata skor : 11.6)Untuk poin Immoderation,poin-poin yang akan diukur adalah sebagai berikut :

a. Go on binges

b. Rarely overindulge

c. Easily resist temptations

d. Able to control my cravings

Vulnerability (rata-rata skor : 11.2) Untuk poin Vulnerability,poin-poin yang akan diukur adalah sebagai berikut :

a. Panic easily

b. Feel comfortable around people

c. Remain calm under pressure
Dari poin -poin yang sudah dijelaskan diatas, berikut adalah model dialog yang ada pada game berikut dengan perhitungan skor yang akan didapat oleh player pada akhir permainan disertai dengan dialog yang ada di dalam game.

\section{Game Concept}

Game Design Document (GDD) mencatat hasil keputusan yang sudah disetujui, mengubah ide yang masih belum jelas menjadi rencana yang eksplisit. Konsep dari game yang akan dibuat adalah sebuah game simulasi yang akan dijadikan sebagai sebuah alat ukur dalam mengukur salah satu bidang kepribadian yaitu neurotisme. Dimana game simulasi ini akan berbentuk sebuah karakter 2D yang berada di dalam satu ruangan dan pada ruangan tersebut, akan dimunculkan sebuah pertanyaan maupun pernyataan yang berkaitan dengan pengukuran neurotisme dari individu tersebut (Muarifah et al., 2019).

\section{Dialog Model}

Dialog model yang ada pada game dibuat berdasarkan pernyataanpernyataan yang ada pada teori Big Five Personality dan digunakan oleh tes IPIP-NEO. Pernyataan-pernyataan yang akan diukur dalam game ini adalah :

Anxiety (rata-rata skor : 13.75) Untuk poin Anxiety, poin-poin yang akan diukur adalah sebagai berikut :

a. Worry about things

b. Fear for the worst

c. Afraid of many things

d. Get stressed out easily

Anger (rata-rata skor : 10.8) Untuk poin anger, poin-poin yang akan diukur adalah sebagai berikut :
a. Get angry easily
b. Get irritated easily
c. Lose temper
d. Not easily annoyed

Depression (rata-rata skor : 10.9)

\section{Hasil Responden}

Responden yang sebelumnya sudah diberikan kuesioner awal, dipersilahkan untuk mencoba game yang sudah dibuat dan diminta untuk menjawab kuesioner tentang hasil dari game yang sudah dibuat tersebut. Berikut hasil kuesioner:

1. $76 \%$ menyatakan bahwa gameplay yang diberikan pada game menarik

2. $68 \%$ menyatakan bahwa gameplay yang diberikan mudah dipahami 
3. $76 \%$ mengatakan bahwa hasil yang mereka dapatkan cukup menggambarkan diri mereka.

4. $84 \%$ responden lebih memilih bermain game dibandingkan dengan kuesioner untuk mengatahui hasil tes neurotisme.

\section{KESIMPULAN}

Berdasarkan hasil evaluasi dari kuesioner, NeuroTest mendapatkan $76 \%$ pengguna yang merasa bahwa hasil dari game memberikan penggambaran yang tepat untuk dirinya. $12 \%$ dari pemain merasa sangat menggambarkan dirinya.

Berdasarkan wawancara dengan DR. Johannes A. A. Rumeser, M.PSI., game ini dinyatakan dapat dijadikan langkah awal untuk mengukur neurotisme dan sebagai alat pengenalan neurotisme sederhana sehingga mencakup tujuan dari penelitian ini.

Menggunakan game sebagai sarana prediksi dan alternatif untuk mengetahui dan mengukur neurotisme seseorang dapat menjadi langkah awal untuk menggunakan game sebagai sarana mengukur neurotisme seseorang.

\section{DAFTAR PUSTAKA}

Dami, Z. A., \& Curniati, S. (2018). Pola Asuh Autoritatif dan Jenis Kelamin sebagai Prediktor Big Five Personality Factors: Implikasinya Bagi Pelayanan Bimbingan dan Konseling. Jurnal Kajian Bimbingan Dan Konseling, 3(4), 182-196. https://doi.org/ 10.17977/um001v3i42018p182

Johnson, J. A. (2014). International Personality Item Pool-NEO-120 (IPIP-NEO-120). 2014. https://doi.org/https://doi.org/10.1037/t3410 2-000

Mastuti, E. (2005). Analisis Faktor Alat Ukur Kepribadian Big Five (Adaptasi dari IPIP) pada Mahasiswa Suku Jawa. Insan, 7(3), 264-276.

Muarifah, A., Fauziah, M., Saputra, W. N. E., \& Da Costa, A. (2019). Pengaruh Regulasi Emosi terhadap Harga Diri Siswa Sekolah Menengah Atas di Yogyakarta. Jurnal Kajian Bimbingan Dan Konseling, 4(3), 94. https://doi.org/10.17977/um001v4i32019p0 94

Pujihastuti, I. (2010). Isti Pujihastuti Abstract. Jurnal Agribisnis Dan Pengembangan Wilayah, 2(1), 43-56.

Sani, A. (2018). Penerapan Metode K-Means Clustering Pada Perusahaan. Jurnal Ilmiah Teknologi Informasi, 353, 1-7. 
